\title{
DNMT3A -448A>G polymorphism and the risk for hepatocellular carcinoma
}

\author{
CHENGCHENG ZHAO $^{1 *}$, FENG YAN $^{2 *}$, HUAZHANG WU $^{1}$, FENGCHANG QIAO $^{1}$, \\ XUEMEI QIU ${ }^{1}$ and HONG FAN ${ }^{1}$ \\ ${ }^{1}$ Department of Medical Genetics and Developmental Biology, Medical School of Southeast University and Key Laboratory \\ of Developmental Genes and Human Diseases, Ministry of Education; ${ }^{2}$ The Jiangsu Cancer Hospital, \\ Nanjing, Jiangsu 210009, P.R. China
}

Received February 22, 2013; Accepted May 20, 2013

DOI: $10.3892 /$ br.2013.121

\begin{abstract}
DNA-methyltransferase (DNMT) 3A plays a significant role in carcinogenesis. Findings of a previous study suggested an association between the DNMT3A -448A $>$ G single-nucleotide polymorphism (SNP) and susceptibility to gastric cancer (GC) and colorectal cancer (CRC). Hepatocellular carcinoma (HCC) is a common malignancy, with a similar expression pattern to GC. The aim of this casecontrol study was to determine whether there is an association between DNMT3A gene polymorphism and susceptibility to HCC. Real-time quantitive PCR (qPCR) was employed to detect DNMT3A expression in tumor and non-cancer liver tissue from 13 HCC patients. An increased expression of DNMT3A was detected, as well as $-448 \mathrm{~A}>\mathrm{G}$ polymorphisms of $D N M T 3 A$ promoter by polymerase chain reaction/restriction fragment length polymorphism (PCR-RFLP), confirmed by sequencing. The distribution of $-448 \mathrm{~A}>\mathrm{G}$ polymorphisms was examined in $108 \mathrm{HCC}$ patients and 225 healthy controls who were matched for age and gender. The association of $-448 \mathrm{~A}>\mathrm{G}$ polymorphisms of DNMT3A and the risk of $\mathrm{HCC}$ was evaluated by stratified analysis according to the patient's age and gender. The allele frequency of $-448 \mathrm{~A}$ among $\mathrm{HCC}$ patients and the controls was 24.07 vs. $24.22 \%$,
\end{abstract}

Correspondence to: Professor Hong Fan, Department of Medical Genetics and Developmental Biology, Medical School of Southeast University and Key Laboratory of Developmental Genes and Human Diseases, Ministry of Education, No. 87 Dingjiaqiao, Nanjing, Jiangsu 210009, P.R. China

E-mail: fanh@seu.edu.cn

*Contributed equally

Abbreviations: PCR, polymerase chain reaction; RFLP, restriction fragment length polymorphism; OR, odds ratio; CI, confidence interval; HCC, hepatocellular carcinoma; SNP, single-nucleotide polymorphism

Key words: hepatocellular carcinoma, DNA-methyltransferase 3A, single-nucleotide polymorphism, susceptibility respectively. The frequency of genotypes GG, AG, AA was 55.56 vs. $56.89 \%, 40.74$ vs. $37.78 \%, 3.7$ vs. $5.33 \%$, respectively. The results indicated that $-448 \mathrm{~A}>\mathrm{G}$ is not associated with susceptibility to $\mathrm{HCC}$, although $-448 \mathrm{~A}>\mathrm{G}$ is a functional single-nucleotide polymorphism (SNP) and increased the expression of DNMT3A in HCC cases. Findings of the present study suggested that the DNMT3A $-448 \mathrm{~A}>\mathrm{G}$ polymorphism is an insufficient biomarker to predict the susceptibility to HCC.

\section{Introduction}

Hepatocellular carcinoma (HCC) is currently the fifth most common solid tumor worldwide and the second leading cause of cancer-related deaths in China $(1,2)$. Although marked progress has been made in recent decades, the details of the molecular mechanisms underlying HCC carcinogenesis remain to be elucidated (3). Survival of patients with HCC has shown improvement with advancements in surgical techniques. However, the median 5-year survival rate remains at $\sim 50 \%$ (4).

Cancer classification using biomarkers may effectively define risk of recurrence, which allows for the use of appropriate treatments in order to obtain a better prognosis (5). However, few measurable biomarkers for predicting HCC recurrence have been identified thus far. Recently, efforts to examine gene methylation by utilizing genome-wide techniques have revealed that a large number of genes exhibit aberrant DNA methylation profiles in cancer (6). These changes can be used to stratify various subtypes of cancer and predict cancer outcomes $(7,8)$. DNA-methyltransferase (DNMT) 3A plays a crucial role in embryonic development and aberrant DNA methylation in carcinogenesis. Polymorphisms of the DNMT3A gene may regulate gene expression, affect its enzymatic activity and potentially contribute to susceptibility to cancer. In a previous study, we found a novel DNMT3A functional single-nucleotide polymorphism (SNP), -448A > G (rs1550117) and demonstrated that a DNMT3A promoter genetic variant increased its transcription activity and contributed to the genetic susceptibility to gastric cancer (GC) and colorectal cancer (CRC) in a Chinese population $(9,10)$. However, an association between the DNMT3A -448A $>\mathrm{G}$ polymorphism and $\mathrm{HCC}$ remains to be elucidated. This study was performed 
to assess the association between rs1550117 in the DNMT3A promoter and the risk for $\mathrm{HCC}$ in a Chinese Han population.

\section{Materials and methods}

Study population and clinical samples. A total of $108 \mathrm{HCC}$ cases and 225 controls were recruited in this case-control study (Table I). Cases and controls were matched by age, gender and were selected from the same hospital. Thirteen fresh HCC tissues and paired adjacent non-cancer tissue samples were randomly selected from patients undergoing hepatectomy from the First Affiliated Hospital of Nanjing Medical University. The samples were obtained following written consent and analyzed anonymously. This study was performed with the approval of the Medical Ethics Committee of the Medical School of Southeast University Key Laboratory of Developmental Genes and Human Diseases, Ministry of Education (Jiangsu, China). Each sample was frozen and stored at $-80^{\circ} \mathrm{C}$. Paired non-cancerous tissues were isolated from at least $2 \mathrm{~cm}$ away from the tumor border.

Real-time quantitive PCR ( $q P C R)$. Total RNA was extracted using TRIzol reagent (Invitrogen, NY, USA). RNA $(1 \mu \mathrm{g})$ was used tosynthesize DNA using the Reverse Transcription System (Promega, Madison, WI, USA). qPCR was performed using the SYBR ${ }^{\circledR}$ Premix Ex Taq ${ }^{\mathrm{TM}}$ (Perfect Real Time; Takara., Otsu, Japan) in an ABI 7300 detection system (Applied Biosystems, Grand Island, NY, USA) according to the manufacturer's instructions. The primers used for the PCR amplifications were: forward: 5'-TATTGATGAGCGCACAAGAGAGC-3' and reverse: 5'-GGGTGTTCCAGGGTAACATTGAG-3'. For the reactions, annealing was carried out at $65^{\circ} \mathrm{C}$, and 40 cycles of amplification were performed. Data were normalized using $\beta$-actin as a reference gene (forward primer: 5'-AAAGACCTGTACGCCAACAC-3' and reverse primer: 5'-GTCATACTCCTGCTTGCTGAT-3'). The relative levels of expression of the target gene among the different samples were calculated accordingly (ABI PRISM 7300 Detection System, USA).

DNA extraction. Venous blood samples $(5 \mathrm{ml})$ were collected in EDTA vacuum tubes from HCC patients and control subjects. Genomic DNA was extracted from white blood cells within a week after sample collection by proteinase $\mathrm{K}$ digestion as previously described (11).

DNMT3A genotyping. The DNMT3A -448A $>\mathrm{G}$ SNP was analyzed by polymerase chain reaction-restriction fragment length polymorphisms (PCR-RFLPs). PCR was performed in a $25 \mu \mathrm{l}$ volume containing $100 \mathrm{ng}$ of genomic DNA, $2.5 \mu \mathrm{l}$ of 10X PCR buffer, $2.0 \mathrm{mM} \mathrm{MgCl}_{2}, 0.1 \mathrm{mM}$ dNTPs (mixture of dATP, dTTP, dCTP and dGTP), 10 pmol of each primer (forward: 5'-ACACACCGCCCTCACCCCTT-3' and reverse: 5'-TCCAGCAATCCCTGCCCACA-3'), 1 unit of Taq DNA polymerase (Biocolor BioScience and Technology Co., Shanghai, China). Amplification was performed as follows: an initial denaturation at $94^{\circ} \mathrm{C}$ for 5 min followed by 32 cycles at $94^{\circ} \mathrm{C}$ for $30 \mathrm{sec}, 66^{\circ} \mathrm{C}$ for $30 \mathrm{sec}, 72^{\circ} \mathrm{C}$ for $30 \mathrm{sec}$, and a final extension at $72^{\circ} \mathrm{C}$ for $10 \mathrm{~min}$. A $10 \mu \mathrm{l}$ aliquot of PCR product was then digested with TaaI (Fermentas Co., Glen Burnie,
Table I. Characteristics of the study population.

\begin{tabular}{lccc}
\hline Variable & $\begin{array}{c}\text { HCC cases } \\
(\mathrm{n}=108) \\
\text { no. }(\%)\end{array}$ & $\begin{array}{c}\text { Controls } \\
(\mathrm{n}=225) \\
\text { no. }(\%)\end{array}$ & P-value \\
\hline $\begin{array}{l}\text { Age, years } \\
<50\end{array}$ & $34(31.48)$ & $57(25.33)$ & 0.239 \\
$\geq 50$ & $74(68.52)$ & $168(74.67)$ & \\
$\begin{array}{l}\text { Gender } \\
\text { Male }\end{array}$ & $85(78.70)$ & $155(68.89)$ & 0.062 \\
Female & $23(21.30)$ & $70(31.11)$ & \\
\hline
\end{tabular}

HCC, hepatocellular carcinoma.

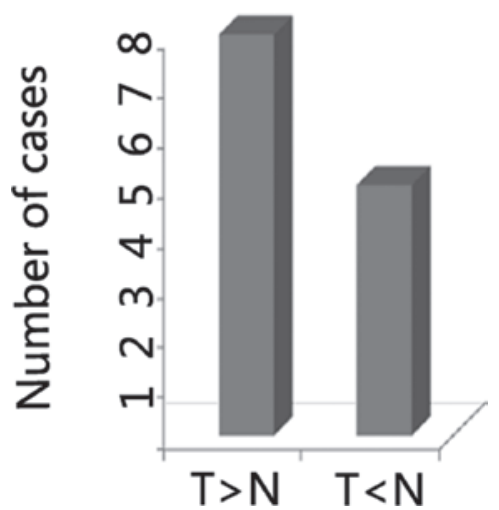

Figure 1. Relative mRNA expression levels of DNA-methyltransferase (DNMT) 3A in HCC patients.

$\mathrm{MD}, \mathrm{USA})$ at $65^{\circ} \mathrm{C}$ for $5 \mathrm{~min}$. Restriction fragments were then separated on a $3.0 \%$ agarose gel stained with ethidium bromide (EB) and visualized under UV light. The wild-type $G$ allele had a TaaI restriction site that resulted in 3 bands $(153,94$ and $87 \mathrm{bp}$ ), while the variant A allele resulted in 4 bands (247, $153,94$ and $87 \mathrm{bp})$. Genotyping quality was evaluated by the repeated genotyping of $10 \%$ randomly selected samples. To confirm the genotyping results, PCR-amplified DNA samples were selected and examined by DNA sequencing.

Statistical analysis. Data were analyzed with SPSS version 13.0 (SPSS Inc., Chicago, IL, USA). Patients and controls were compared using the Student's t-test for continuous variables and the Chi-square $\left(\chi^{2}\right)$ test for categorical variables. Allele and genotype frequencies between control and HCC subjects were obtained using the Chi-square $\left(\chi^{2}\right)$ test, and the standard goodness-of-fit test was used to test the Hardy-Weinberg equilibrium. $\mathrm{P}<0.05$ was considered statistically significant.

\section{Results}

Previously, we revealed the depletion of DNMT3A suppressed cell proliferation in HCC cells (1). In the present study, we found that the frequency of overexpression of $D N M T 3 A$ was $62 \%$ in HCC, which was higher than that in the non-cancer cases (Fig. 1). These data suggested that DNMT3A is involved in the development of carcinogenesis. Recently, we found 
Table II. DNMT3A -448A>G genotype and allele frequency among cases and controls and association with HCC.

\begin{tabular}{|c|c|c|c|c|}
\hline Genotype/allele & $\begin{array}{l}\mathrm{HCC}(\mathrm{n}=108) \\
\text { No. }(\%)\end{array}$ & $\begin{array}{c}\text { Control subjects }(\mathrm{n}=225) \\
\text { No. }(\%)\end{array}$ & Crude OR $(95 \%$ CI) & $\mathrm{P}-$ value $^{\mathrm{a}}$ \\
\hline \multicolumn{5}{|l|}{ Genotype } \\
\hline $\mathrm{AA}$ & $4(3.70)$ & $12(5.33)$ & 1 & \\
\hline $\mathrm{AG}$ & $44(40.74)$ & $85(37.78)$ & $1.553(0.473-5.098)$ & 0.465 \\
\hline GG & $60(55.56)$ & $128(56.89)$ & $1.406(0.435-4.542)$ & 0.567 \\
\hline \multicolumn{5}{|l|}{ Allele } \\
\hline A & $52(24.07)$ & $109(24.22)$ & 1 & \\
\hline $\mathrm{G}$ & $164(75.93)$ & $341(75.78)$ & $1.008(0.690-1.473)$ & 0.967 \\
\hline
\end{tabular}

${ }^{\mathrm{a} C h i}$-square $\left(\chi^{2}\right)$ test. DNMT3A, DNA-methyltransferase 3A; HCC, hepatocellular carcinoma; OR, odds ratio; CI, confidence interval.

Table III. DNMT3A -448 A>G genotypes and allele frequencies in HCC cases.

\begin{tabular}{|c|c|c|c|c|c|}
\hline \multirow[b]{2}{*}{$\begin{array}{l}\text { Group } \\
\text { P-value }^{a}\end{array}$} & \multicolumn{3}{|c|}{ Genotype } & \multirow{2}{*}{ 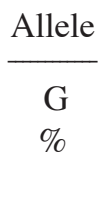 } & \\
\hline & $\begin{array}{c}\text { AA } \\
\text { No. }(\%)\end{array}$ & $\begin{array}{c}\text { AG } \\
\text { No. }(\%)\end{array}$ & $\begin{array}{c}\text { GG } \\
\text { No. }(\%)\end{array}$ & & \\
\hline Total & $4(3.70)$ & $44(40.74)$ & $60(55.56)$ & 75.93 & \\
\hline Age, years & & & & & $0.248^{b}$ \\
\hline$<50$ & $2(1.85)$ & $9(8.33)$ & $23(21.30)$ & 80.88 & \\
\hline$\geq 50$ & $2(1.85)$ & $35(32.41)$ & $37(34.26)$ & 73.65 & \\
\hline Gender & & & & & $0.420^{\mathrm{c}}$ \\
\hline Male & $4(3.70)$ & $35(32.41)$ & $46(42.60)$ & 74.71 & \\
\hline Female & $0(0.00)$ & $9(8.33)$ & $14(12.96)$ & 80.43 & \\
\hline
\end{tabular}

${ }^{\mathrm{a}} \mathrm{Chi}$-square $\left(\chi^{2}\right)$ test. ${ }^{\mathrm{b}}$ Frequency of $\mathrm{G}$ allele in individuals at age range $<50$ vs. $\geq 50$ years. ${ }^{\mathrm{c}}$ Frequency of $\mathrm{G}$ allele in individuals in male vs. female. DNMT3A, DNA-methyltransferase 3A; HCC, hepatocellular carcinoma.

Table IV. Distribution of 448 A > G DNMT3A genotypes and associated OR in relation to age and gender in HCC cases.

\begin{tabular}{|c|c|c|c|c|c|}
\hline Characteristics & Genotype & $\begin{array}{c}\text { HCC cases } \\
\text { No. }(\%)\end{array}$ & $\begin{array}{l}\text { Controls } \\
\text { No. }(\%)\end{array}$ & OR $(95 \% \mathrm{CI})$ & P-value \\
\hline Male & $\begin{array}{c}\mathrm{AA} \\
\mathrm{AG}+\mathrm{GG}\end{array}$ & $\begin{array}{c}4(3.70) \\
81(75.00)\end{array}$ & $\begin{array}{c}11(4.89) \\
144(64.00)\end{array}$ & $\begin{array}{c}1 \\
1.547(0.477-5.016)\end{array}$ & 0.464 \\
\hline \multicolumn{6}{|l|}{ Age, years } \\
\hline$<50$ & $\begin{array}{c}\mathrm{AA} \\
\mathrm{AG}+\mathrm{GG}\end{array}$ & $\begin{array}{c}2(1.85) \\
26(24.07)\end{array}$ & $\begin{array}{c}5(2.22) \\
41(18.22)\end{array}$ & $\begin{array}{c}1 \\
1.585(0.286-8.782)\end{array}$ & 0.595 \\
\hline$\geq 50$ & $\begin{array}{c}\mathrm{AA} \\
\mathrm{AG}+\mathrm{GG}\end{array}$ & $\begin{array}{c}2(1.85) \\
45(41.67)\end{array}$ & $\begin{array}{c}6(2.67) \\
103(45.78)\end{array}$ & $\begin{array}{c}1 \\
1.311(0.255-6.744)\end{array}$ & 0.746 \\
\hline Female & $\begin{array}{c}\mathrm{AA} \\
\mathrm{AG}+\mathrm{GG}\end{array}$ & $\begin{array}{c}0(0.00) \\
23(21.30)\end{array}$ & $\begin{array}{c}1(0.44) \\
69(30.67)\end{array}$ & $\begin{array}{c}1 \\
0.750(0.667-0.844)\end{array}$ & 1 \\
\hline \multicolumn{6}{|l|}{ Age, years } \\
\hline$<50$ & $\begin{array}{c}\mathrm{AA} \\
\mathrm{AG}+\mathrm{GG}\end{array}$ & $\begin{array}{l}0(0.00) \\
6(5.56)\end{array}$ & $\begin{array}{r}0(0.00) \\
11(4.89)\end{array}$ & - & - \\
\hline$\geq 50$ & $\begin{array}{c}\mathrm{AA} \\
\mathrm{AG}+\mathrm{GG}\end{array}$ & $\begin{array}{c}0(0.00) \\
17(15.74)\end{array}$ & $\begin{array}{c}1(0.44) \\
58(25.78)\end{array}$ & $0.773(0.684-0.874)$ & 1 \\
\hline
\end{tabular}

DNMT3A, DNA-methyltransferase 3A; HCC, hepatocellular carcinoma; OR, odds ratio; CI, confidence interval. 
that a functional SNP of DNMT3A $-448 \mathrm{~A}>\mathrm{G}$ polymorphism affected the promoter activity of DNMT3A. Thus, we hypothesized that DNMT3A promoter SNP (rs1550117) variants may have an effect on DNMT3A expression in HCC.

We genotyped the DNMT3A promoter $-448 \mathrm{~A}>\mathrm{G}$ polymorphisms in 108 HCC patients and 225 controls by PCR-RFLP. The genotyping was confirmed by DNA sequencing, and the results of the PCR-RFLP genotyping and sequencing analysis were $100 \%$ concordant. The genotypic and allelic frequencies of DNMT3A -448A>G are summarized in Tables I and II. The distributions of $-448 \mathrm{~A}>\mathrm{G}$ genotypes in the $\mathrm{HCC}$ were AA, 3.70\%; AG, 40.74\%; GG, 55.56\%. The A allele frequency was $24.07 \%$, while the frequency for the controls was 5.33 , $37.78,56.89 \%$, respectively, and $24.22 \%$ for the A allele. No significant differences were observed in the genotypic and allelic frequencies in the two groups. HCC was then stratified by age and gender. No significantly different frequencies of $-448 \mathrm{~A}>\mathrm{G}$ were observed in $\mathrm{HCC}$ patients (Table III).

The DNMT3A -448A $>\mathrm{G}$ polymorphism was evaluated in relation to the risk of $\mathrm{HCC}$ in this case-control study. The HCC patients and control subjects were first grouped by gender (male and female), and then by age ( $<50$ and $\geq 50$ years). The genotype and allele frequencies were evaluated, the OR and their $95 \%$ confidence intervals (CIs) were calculated using the more common homozygous variant genotype as the reference group. No differences between the HCC patients and control subjects were observed (Table IV).

\section{Discussion}

$\mathrm{HCC}$ is one of the most common malignant tumors, with a poor survival rate. It is particularly prevalent in China and Asia. While surgery is the most effective treatment for liver tumor, $\sim 80 \%$ of HCC patients are inoperable at presentation and succumb to the disease early due to late diagnosis (12). The development of biomarkers for the early diagnosis and accurate prognosis of HCC is crucial for improving patient survival. Various tissue and serum potential biomarkers including AFP-L3, DCP, AFP, and hepatocyte growth factor (HGF) are involved in HCC (13).

In mammals, DNA methylation is essential for embryonic development and is involved in gene expression, genomic imprinting, $\mathrm{X}$ chromosome inactivation, and maintenance of genome integrity. Aberrant changes of genomic methylation patterns or abnormal interpretation of the DNA methylation signals are associated with several human disorders, most notably immunodeficiency, centromeric instability, facial anomalies syndrome, Rett syndrome and cancer (14). The expression of these DNMTs is significantly elevated in various types of cancer including breast, colon, endometrium, prostate, stomach and in uterine leiomyomata (15). In a previous study, DNMT3A expression was increased in 3/6 HCC cell lines and 16/25 (64\%) HCC tissues, suggesting that DNMT3A is involved in hepatocellular carcinogenesis (16). Abnormal DNA methylation can lead to tumor suppressor gene silencing by DNA methylation on $\mathrm{CpG}$ islands in their promoter regions in cancer cells, and thus the overall level of DNA methylation is higher in cancer cells compared with normal cells $(17,18)$. SNPs of DNMTs are important indicators of genetic susceptibility to cancer development. Therefore, genetic polymorphism assays have been used to investigate the aetiology of malignant diseases (19).

Little is known about the association of DNMTs and the genetic susceptibility to HCC. Therefore, we investigated the effect of DNMT3A polymorphisms $-448 \mathrm{~A}>\mathrm{G}$ and risk of HCC in a hospital-based case-control study in a Chinese population. Overexpression of DNMT3A was detected in $\mathrm{HCC}$ cases at the transcription level. The functional SNP $-448 \mathrm{~A}>\mathrm{G}$ of DNMT3A was evaluated in HCC patients and healthy controls as a case-control study. The results suggest that the DNMT3A 448A>G polymorphism was not associated with the risk of $\mathrm{HCC}$ in the study population. This finding was different from those of previous studies (11) possibly due to the genetic background of HCC being different from that of GC and CRC. In addition, DNMT3A has four alternatively spliced variants, and different isoforms of the same enzyme may have altered catalytic activity or target-site specificity that may play different roles in carcinogenesis (20). However, additional studies with larger sample sizes and different populations are required to confirm findings of the present study.

In conclusion, to the best of our knowledge, this is the first report to investigate the association of an SNP in DNMT3A with genetic susceptibility to HCC. This finding may provide valuable insight into hepacellular carcinogenesis, although the result that DNMT3A-448A $>\mathrm{G}$ SNP is associated with the susceptibility to $\mathrm{HCC}$ should be investigated.

\section{Acknowledgements}

This study was supported by The National Natural Science Foundation of China, nos. 81171915 and 91229107.

\section{References}

1. Thomas MB, Jaffe D, Choti MM, et al: Hepatocellular carcinoma: consensus recommendations of the National Cancer Institute Clinical Trials Planning Meeting. J Clin Oncol 28: 3994-4005, 2010.

2. El-Serag HB and Rudolph KL: Hepatocellular carcinoma: epidemiology and molecular carcinogenesis. Gastroenterology 132: 2557-2576, 2007.

3. Hanahan D and Weinberg RA: Hallmarks of cancer: the next generation. Cell 144: 646-674, 2011.

4. Takayama T: Surgical treatment for hepatocellular carcinoma. Jpn J Clin Oncol 41: 447-454, 2011.

5. Fernandez M, Semela D, Bruix J, Colle I, Pinzani M and Bosch J: Angiogenesis in liver disease. J Hepatol 50: 604-620, 2009.

6. Figueroa ME, Lugthart S, Li Y, et al: DNA methylation signatures identify biologically distinct subtypes in acute myeloid leukemia. Cancer Cell 17: 13-27, 2010.

7. Noushmehr H, Weisenberger DJ, Diefes K, et al: Identification of a $\mathrm{CpG}$ island methylator phenotype that defines a distinct subgroup of glioma. Cancer Cell 17: 510-522, 2010.

8. Portela A and Esteller M: Epigenetic modifications and human disease. Nat Biotechnol 28: 1057-1068, 2010.

9. Fan H, Liu D, Qiu X, et al: A functional polymorphism in the DNA methyltransferase-3A promoter modifies the susceptibility in gastric cancer but not in esophageal carcinoma. BMC Med 8: 12, 2010.

10. Zhao Z, Li C, Song Y, Wu Q, Qiao F and Fan H: Association of the DNMT3A -448A>G polymorphism with genetic susceptibility to colorectal cancer. Oncol Lett 3: 450-454, 2012.

11. Miller SA, Dykes DD and Polesky HF: A simple salting out procedure for extracting DNA from human nucleated cells. Nucleic Acids Res 16: 1215, 1988.

12. Sun S, Xu MZ, Poon RT, Day PJ and Luk JM: Circulating Lamin B1 (LMNB1) biomarker detects early stages of liver cancer in patients. J Proteome Res 9: 70-78, 2010. 
13. Behne $\mathrm{T}$ and Copur MS: Biomarkers for hepatocellular carcinoma. Int J Hepatol: 859076, 2012.

14. Chen T and Li E: Structure and function of eukaryotic DNA methyltransferases. Curr Top Dev Biol 60: 55-89, 2004

15. Kurkjian C, Kummar S and Murgo AJ: DNA methylation: its role in cancer development and therapy. Curr Probl Cancer 32: $187-235,2008$

16. Zhao Z, Wu Q, Cheng J, Qiu X, Zhang J and Fan H: Depletion of DNMT3A suppressed cell proliferation and restored PTEN in hepatocellular carcinoma cell. J Biomed Biotechnol: 737535 2010.

17. Paz MF, Fraga MF, Avila S, et al: A systematic profile of DNA methylation in human cancer cell lines. Cancer Res 63: 1114-1121, 2003.
18. Egger G, Liang G, Aparicio A and Jones PA: Epigenetics in human disease and prospects for epigenetic therapy. Nature 429: 457-463, 2004

19. Wjst M: Target SNP selection in complex disease association studies. BMC Bioinformatics 5: 92, 2004.

20. Robertson KD, Uzvolgyi E, Liang G, et al: The human DNA methyltransferases (DNMTs) 1, 3a and 3b: coordinate mRNA expression in normal tissues and overexpression in tumors. Nucleic Acids Res 27: 2291-2298, 1999. 